\title{
HOMER3 wt Allele
}

National Cancer Institute

\section{Source}

National Cancer Institute. HOMER3 wt Allele. NCI Thesaurus. Code C104573.

Human HOMER3 wild-type allele is located in the vicinity of 19p13.11 and is approximately $12 \mathrm{~kb}$ in length. This allele, which encodes homer protein homolog 3 protein, is involved in protein localization at the postsynaptic density. 